\title{
ANALISIS PENULISAN AL-KÂMIL FÎ AL-TÂRIKKH KARYA IBN AL-ATSIR
}

\author{
Shidqy Munjin, Satria Setiawan \\ Pascasarjana UIN Sunan Gunung Djati Bandung \\ Email:aqautsar@gmail.com
}

\begin{abstract}
Al-Kâmil fî al-Târikkh is the most important work of Ibn al-Athir. Ibn al-Athir wrote this work by collecting data from his predecessors and adding to the events that occurred during his time. Ibn al-Athir wrote down all the events witnessed by his own eyes, especially those relating to the saliibn war. This paper attempts to analyze and compare the work of Ibn al-Athir in terms of historical aspects that developed in the Islamic world during his time, especially with Târikh al-Rusul wa al-Muluk by Ibn Jarir alTabari. The research method used in this study was library research, where the study was explained descriptively and critically analyzed. Then the type of data used is literature literary data, both primary and secondary. The results of this study indicate that Ibn al-Athir with his work al-Kâmil fî al-Tîrikh was a initiator of a new historical study in the Islamic world.
\end{abstract}

Keyword : Ibn al-Atsir, al-Thabari, al-Kâmil fî al-Târîkh.

\begin{abstract}
Abstrak
Al-Kâmil fî al-Târîkh merupakan karya terpenting dari Ibn al-Atsir. Ibn al-Atsir menulis karyanya ini dengan mengumpulkan data-data dari para pendahulunya dan ditambahkan dengan kejadian yang terjadi pada masanya. Ibn al-Atsir menuliskan semua kejadian yang disaksikan oleh matanya sendiri, terutama yang berkaitan dengan perang saliibn Tulisan ini mencoba menganalisis dan membandingkan karya Ibn al-Atsir tersebut ditinjau dari aspek ilmu kesejarahan yang berkembang di dunia Islam pada masanya, terutama dengan Târikh al-Rusul wa al-Muluk karya Ibn Jarir alThabari. Metode penelitian yang digunakan dalam kajian ini adalah riset kepustakaan, dimana kajiannya dijelaskan secara deskriptif dan analisis kritis. Kemudian jenis data yang digunakan adalah data literer kepustakaan, baik primer maupun sekunder. Hasil penelitian ini menunjukkan bahwa Ibn al-Atsir dengan karyanya al-Kâmil fì al-Târîkh merupakan seorang penggagas kajian kesejarahan yang baru dalam dunia Islam.
\end{abstract}

Kata Kunci: Ibn al-Atsir, al-Thabari, al-Kâmil fî al-Târîkh. 


\section{A. Pendahuluan}

Salah satu peninggalan ilmu terpenting dalam Islam ialah penulisan sejarah atau historiografi. Sejak pertengahan abad ke-2, penulisan sejarah, baik riwayat hidup Nabi Muhammad saw. atau yang lainnya telah dirintis oleh para ulama Islam. Penulisan sejarah dalam Islam diawali oleh para ahli hadits untuk kepentingan kritik rawi. Maka kajian kesejarahan pada masa awal-awal Islam lebih bersifat biografi (tarâjim).

Beberapa model penulisan biografi dalam Islam, diantaranya thabaqât, alnasab, manâqîb, dan sîrah. Semuanya ditulis untuk kepentingan ilmu hadits. Selain itu, orang-orang Arab merupakan orang yang sangat membanggakan nasab dan sukunya. Sehingga mereka sangat menjaga tradisi nasab tersebut, baik secara lisan maupun tulisan.

Dalam tradisi keilmuan Islam, banyak sekali ditemukan karya para ulama mengenai biografi orang-orang penting. Mulai yang ditulis oleh generasi abad ke dua sampai generasi abad pertengahan. Karya seperti thabaqât Ibn Sa'd, Târîkh al-Bukhari, al-Jarh wa al-Ta'dîl Ibn Abi Hatim, sampai dengan siyar al-A'lâm alNubalâ' Imam al-Dzahabi, Thabaqât al-Kubrâ al-Sya'rani, dan karya biografi lainnya menggambarkan bentuk penulisan sejarah dalam Islam. ${ }^{1}$

Penulisan sejarah yang agak berbeda dengan penulisan sejarah masa-masa awal Islam, dirintis oleh Ibn Jarir al-Thabari dengan Târîkh al-Rusul wa al-Muluk. Al-Thabari menuliskan sejarah bukan sekedar bigrafi para ulama. Beliau menuliskan sejarah dalam bentuk kolektif. Jika tradisi penulisan sejarah pada masa awal seringkali mengikuti seleksi riwayat yang begitu ketat dengan pola standar ilmu hadits, maka pada periode pasca al-Thabari, sejarah ditulis dengan cara yang lebih mudah dan longgar. ${ }^{2}$

Jejak al-Thabari ini merupakan pembuka jalur bagi ulama setelahnya untuk menuliskan sejarah sosial secara lebih utuh. Maka muncul beberapa ulama yang meneruskan jejak langkah al-Thabari. Salah satu di antara mereka adalah Izzuddin Ibn al-Atsir dengan karyanya yang berjudul al-Kâmil fî al-Târîkh.

Karya Ibn al-Atsir ini bisa dianggap sebagai karya penyempurna dari karya al-Thabari. Bila al-Thabari menuliskan sampai masa dia hidup, yaitu sampai $310 \mathrm{H}$, maka Ibn al-Atsir meneruskannya sampai dengan masa hidupnya, yaitu sampai $630 \mathrm{H}$. Masa hidup Ibn al-Atsir bisa dikatakan merupakan masa yang lebih penting untuk dicatat daripada masa hidup al-Thabari. Pada masa Ibn alAtsir inilah terjadi perang agama terbesar, yaitu Perang Salib. Namun yang lebih penting dari itu, Ibn al-Atsir mencoba menuliskan sejarah dengan perspektif yang

${ }^{1}$ Untuk kajian ini bisa dilihat dalam, Ajid Thahir, Sirah Nabawiyyah, (Bandung: Marja, 2014), hal. 42-51.

${ }^{2}$ Untuk kajian ini bisa dilihat dalam, Ajid Thahir, Sirah Nabawiyyah. 
baru. Ibn al-Atsir tidak hanya mengikuti jejak langkah al-Thabari, namun juga melakukan pembaruan dan langkah baru dalam penulisan sejarah. Tulisan ini akan mencoba mengkaji karya Izzuddin ibn al-Atsir tersebut.

\section{B. Biografi Izzuddin Ibn al-Atsir}

Beliau adalah pengarang buku Al-Kamil fi al-tarikh, salah satu buku sejarah yang berpengaruh terhadap semua pembaca dan peneliti baik dari Timur maupun dari Barat. Dia adalah seorang ilmuwan yang terkenal. Spesialisnya alQuran, hadits, dan Nahwu. Buku Al-Kâmil fî Al-Târîkh merupakan ensklopedia sejarah umum besar untuk dunia Islam, dan merupakan ringkasan yang sangat memadai untuk tulisan kaum muslim mengenai sejarah politik mereka.

Nama lengkap beliau adalah Izzuddin Abu al-Hasan, 'Ali ibn Muhammad ibn Abd al-Karim ibn 'Abd al-Wahid, yang terkenal dengan nama Ibn Al-Atsir, Abu al-Karam, al-Syaibani, al-Jazari. Al-Jazari adalah penyandaran ke daerah Jazirah, yang terletak antara sungai Tigris dan Eufrat. Daerah tersebut terkenal dengan nama Jazirah Ibn 'Umar. ${ }^{3}$ Dia dilahirkan pada tanggal 4 Jumâdâ al-Ûlâ tahun 555 H (1160 M) di Jazirah Ibn Umar. Kemudian ia pindah dan menetap untuk mencari ilmu di Mosul. Dia pun beberapa kali pergi ke Baghdad, Syam, alQuds, dan kemudian akhirnya kembali ke Mosul dan menetap di rumahnya untuk memfokuskan diri dalam menulis. Rumahnya di Mosul merupakan tempat berkumpulnya orang Mosul pada waktu itu.

Beliau juga adalah seorang yang sangat terpercaya keilmuannya dalam bidang sejarah, baik masa lalu maupun yang semasa dengannya. Ibn al-Atsir tidak hanya mengusai sejarah, tetapi juga menguasai ilmu Hadits, Sirah Nabi, garis keturunan ('ilm al-ansâl) bangsa Arab, dan hari-hari kejayaan mereka. Dia juga menulis riwayat hidup para shahabat Nabi yang berjudul "Usud al-Ghâbah fî Tamyîz al-Shahâbah" yang merupakan kitab biografi yang memuat kira-kira 700 biografi para shahabat Nabi. Beliau juga menyusun sebuah kitab berjudul "alKâmil fî al-Târîkh" yang merupakan edisi ringkas dari karya at-Thabari. ${ }^{4}$ Kitab ini merupakan karya terbesar yang dihasilkan oleh Ibn al-Atsir.

Ibn Khalikan menyebutkan bahwa ketika Ibn al-Atsir tiba di Aleppo di akhir tahun $626 \mathrm{H}$, beliau singgah di rumah al-Thawwasy Syihabuddin Thughrail, salah seorang bawahan Sultan Atabik. Ibn Khalikan pun pernah berjumpa dengan Ibn al-Atsir di Aleppo. Ibn Khalikan memujinya sebagai orang yang memiliki

3 Ibn Khalikan, Wafayât al-A'yân, juz 3, hal. 348-350. Ibn Khalikan belum bisa memastikan siapa yang dimaksud dengan Ibn Umar ini. Ada yang mengatakan beliau ialah Yusuf ibn Umar al-Tsaqafi, salah seorang pemimpin Iraq. Adapula yang mengatakan bahwa dia adalah 'Abd al-'Aziz ibn Umar yang membangun kota Mosul. Dan ada pula yang mengatakan selain dari pada itu.

${ }^{4}$ Lihat Ibn al-Atsîr, Usud al-Ghâbah fî Tamyîz al-Shahâbah, (Mesir: Dar al-Kutub al'Ilmiyyah, 1994), dicetak dalam 8 jilid. 
banyak keutamaan, berakhlak baik, dan sangat rendah hati. Ibn. Khalikan merupakan salah satu ulama yang sempat ber-mulâzamah (belajar secara intens) dengan Ibn al-Atsir. ${ }^{5}$

Ibn al-Atsir adalah salah seorang di antara tiga orang bersaudara yang terkenal dalam tradisi keilmuan. Majd al-Din ibn al-Atsir, seorang ahli hadits yang menulis al-Nihâyah fì Gharîb al-Hadîts wa al-Atsar. Kemudian Dhiya' alDin ibn al-Atsir, seorang yang ahli dalam bidang adab dan surat-menyurat yang menulis al-Matsal al-Sâir fî Adab al-Kâtib wa al-Syâ'ir. Dan terakhir, seorang yang sedang dibahas pada tulisan ini, 'Izzuddin ibn al-Atsir, seorang ahli sejarawan yang menulis al-Kâmil fì al-Târîkh.

Pengembaraan intelektualnya yang panjang menuntut ilmu dengan bergaul dan belajar dari berbagai ulama, Ibn Atsir menekuni bidang-bidang kajian, semisal: hadits. Fiqh, uhuluddin, farâid (ilmu waris), Logika (mantiq) dan ilmu qirâ'at. Keahliannya di berbagai bidang itu berkat pergaulannya yang panjang dengan berbagai ulama yang terpandang yang dijumpainya. Meski demikian, dia lebih spesifik mendalami dua bidang kesarjanaan: sejarah dam hadits, sampai dikenal sebagai pemuka (imâm) di bidang hadits dan kajian yang berkaitan dengannya dan ahli yang mumpuni (hâfiz) di bidang kesejarahan baik sejarah kuno maupun sejarah kontemporer pada zamannya. Pada kedua bidang itulah Ibn Atsir mendapatkan namanya di kalangan intelektual zamannya. Akan tetapi keahliannya yang luar biasa di bidang sejarah inilah seakan-akan menutupi kenyataan bahwa dia adalah seorang serba bisa pada bidang kajian keilmuan lainnya.

Sebenarnya kaitan bidang keahlian pada ilmu hadits dan sejarah begitu erat. Biasanya seorang sejarawan besar adalah sekaligus seorang ahli ilmu hadits terkemuka. Contoh paling baik untuk ini adalah Imam al-Thabari yang serba bisa. Dia menghimpun pada dirinya keahlian dalam displin ilmu-ilmu eksegesis Qur'an (tafsîr), jurisprudensi Islam, dan ilmu sejarah. contoh lainnya ialah seorang tokoh bernama Imam Dzahabi, penghafal hadits yang cermat sekaligus sejarawan terkemuka. Al-hâfiz Ibn 'Asakir juga menghimpun dalam dirinya keahlian pada dua subjek kajian ini. Masih banyak contoh lainnya yang tidak bisa disebutkan di sini.

Menjelang masa-masa pengembaraannya berakhir, Ibn Atsir bermukim di Mosul, dengan menyibukkan diri pada penulisan dan penyusunan karya-karyanya sekaligus menggeluti karirnya di pemerintahan, yang membuatnya berkecukupan dan terpandang. Rumah kediamannya menjadi pertemuan para pengunjung dan

${ }^{5}$ Ibn Khalikan, Wafayât al-A'yân, juz 3, h. 348-350. 
penuntut ilmu. Ibn al-Atsir wafat pada bulan Sya'ban tahun $630 \mathrm{H}(1233 \mathrm{M})$. Imam al-Dzahabi memuji beliau dengan julukan imam, sejarawan dan ahli adaibn ${ }^{6}$

\section{Analisis Kitab al-Kâmil fì al-Târîkh}

\section{Biografi Kitab al-Kâmil fî al-Târîkh}

Kitab ini berjudul al-Kâmil fî al-Târîkh, berjumlah tujuh juz, ${ }^{7}$ yang ditulis oleh 'Izzuddin ibn al-Atsir. Kitab ini merupakan kitab rujukan dalam bidang sejarah dan paling terkenal pada abad pertengahan. Hal ini dikarenakan kitab ini menghimpun sejarah Islam secara keseluruhan, dari mulai India, Cina, semua wilayah timur bahkan hingga Andalusia di Barat. ${ }^{8}$

Al-Kâmil fî al-Târîkh dianggap karya terpenting Ibn al-Atsir di bidang sejarah, karena kitab ini mencakup kajian sejarah umum Dunia Islam dimulai dari masa khalifah, seperti tradisi mayoritas ahli sejarah Islam, hingga catatan akhir tahun $628 \mathrm{H}$. Bahkan, karya ini juga dianggap karya paling penting mengenai sejarah Islam. Penulis menempuh metode yang berimbang dalam uraian sejarah setiap daerah Islam; membandingkan berbagai peristiwa yang terjadi di setiap daerah berdasarkan kronologi tahun; dan mengandalkan para spesialis sejarah setiap daerah.

Kitab al-Kâmil fî al-Târîkh merupakan antara kitab sejarah terbesar yang pernah dihasilkan oleh Ibn al-Atsir. Perbahasan sejarah dalam kitab ini bermula daripada sejarah permulaan atau penciptaan alam dan makhluk sampai masa hidupnya Ibn al-Atsir, yaitu tahun 628H/1230M. Kitab ini ditulis berdasarkan gaya penulisan kitab al-Târîkh al-Thabari karya Imam Muhammad ibn Jarir alThabari. Para sarjana sangat mengagumi kitab al-Kâmil fî al-Târîkh metode penulisannya yang memberikan suatu bentuk pengumpulan peristiwa sejarah yang unik dengan menyediakan episod-episod sejarah yang disertai penjelasan kerangka sejarahnya. Selain itu, isi kandungannya merupakan hasil penelitian kembali terhadap bahan-bahan sejarah yang pernah disusun sebelumnya. Hal ini menjadikan karyanya ini mendapatkan penghargaan dan digunakan sebagai sumber di dalam penyusunan buku-buku sejarah Islam. Berdasarkan kenyataan tersebut, tidak heran sekiranya metode penulisan dan kandungan sejarah dalam al-

${ }^{6}$ Syamsuddin al-Dzahabi, Târîkh al-Islâm, no. 599. Untuk biografi Ibn al-Atsir bisa dilihat dalam; Ibn Khalikan, Wafayât al-A'yân, juz 3, h. 348-350. Syamsuddin al-Dzahabi, alI'lâm bi Wafayât al-A 'lâm, hal. 260. Al-Dzahabi, Tadzkirat al-Huffâdzi, juz 4, hal. 1399. AlSubki, Thabaqât al-Syâfi 'iyyah al-Kubrâ, juz 5, hal. 127. Al-Shafadi, al-Wâfî wa al-Wâfiyât, juz 22, hal. 136-137, no. 82. Ibn al-Imad al-Hanbali, Syadzarât al-Dzahab, juz 5, h. 137. Dan masih banyak kitab biografi yang lainnya.

${ }^{7}$ Ada beberapa penerbit yang membaginya menjadi 12 jilid.

${ }^{8}$ Ibn al-Atsir, al-Kâmil fî al-Târîkh (Beirut: Dar al-Kutub al-‘Arabi, 1997), juz 1, hal. ي. 
Kâmil fî al-Târîkh mempengaruhi penulisan karya sejarah setelahnya, di antaranya adalah kitab al-Bidâyah wa al-Nihâyah karya Ibn Katsir.

Pendekatan pensejarahan dalam kitab ini yaitu sistem kronologi yang memudahkan pengkaji sejarah untuk meneliti peristiwa sejarah yang telah terjadi. Perbahasan berkaitan sejarah Islam ditulis oleh Ibn al-Atsir di dalam karya sejarah beliau. Perbahasan tersebut lebih tertumpu kepada peristiwa peperangan dan futûhât al-Islâmiyyah, khususnya ketika era 'Abbasi dengan fokus pembahasan diberikan kepada Kerajaan Ghaznawi. ${ }^{9}$

Sebenarnya kitab ini bisa dikatakan sebagai ringkasan dari kitab Târîkh alRusul wa al-Mulûk karya Imam al-Thabari. Namun dalam periwayatannya, ibnu al-Atsir menganggap cukup satu riwayat yang diterimanya. Kemudian beliau melengkapinya dengan informasi yang belum ada pada Thabari, yang ia ambil dari Ibn al-Kalbi, al-Mubarrid, al-Baladzuri dan lain-lain, ditambah dengan peristiwa yang ia saksikan dengan mata kepalanya sendiri. ${ }^{10}$

Kontribusi Ibn Al-Atsir terletak pada metodenya dalam memaparkan fakta-fakta sejarah. Ia membuang detail-detail uraian yang tidak diperlukan, sangat teliti dalam memverifikasikan referensi, hanya memilih data-data yang sesuai fakta, dan meringkas peristiwa-peristiwa yang terjadi selama setahun.

Kaedah penulisan Ibn al-Atsir berdasarkan kronologi atau urutan peristiwa sebagaimana kaedah yang digunakan oleh al-Tabari dalam karya al-Tarikh. Ibn al-Atsir menyusun dan mengumpulkan peristiwaperistiwa kecil yang berlaku dalam satu-satu tahun dan mengakhiri dengan tarikh kewafatan tokoht-okoh terkenal. Ketika membicarakan peristiwa-peristiwa besar dan penting, Ibn al-Atsir akan mengkhususkannya di bawah tajuk-tajuk tertentu di dalam tahun ia berlaku. Ibn al Atsir tidak membicarakan peristiwa-peristiwa yang berlaku dalam satu-satu tahun secara meleret hingga masuk ke tahun-tahun berikutnya kecuali untuk menjaga kesinambungan peristiwa tersebut dan mengelakkan plot penceritaan sejarah terputus.

Ibn. al-Atsir berpendapat kaedah pensejarahan secara kronologi mempunyai kelemahannya tersendiri. Menurut beliau, kaedah ini boleh memutuskan jalinan atau kesinambungan sesuatu peristiwa sehingga beberapa tahun. Kaedah ini juga tidak memperlihatkan jalinan yang kemas dalam sesuatu peristiwa. Justru, Ibn al-Atsir berusaha sebaiknya dengan mengolah sesuatu peristiwa dalam sesebuah tempat walaupun peristiwa tersebut berterusan untuk beberapa tahun. Selain itu, Ibn al-Atsir turut memberi ulasan tentang sesuatu perkara dan membuat kritikan terhadap beberapa riwayat terutama ketika

\footnotetext{
${ }^{9}$ Koes Adiwijajanto, Historicum Camalitatum Dunia Islam dalam Historiografi Ibn alAtsir, Jurnal Cordoba, Vol. 1, no.1, 2017, hal. 37.

${ }^{10}$ Article in Jurnal, h. 6.
} 
membincangkan sejarah Kerajaan Ayyubiyah, Zankiyyah, Salibiyyah dan Mongol. Gaya bahasa Ibn al-Atsir pula mudah difahami dan kadang kala diselit dengan ayat al-Qur'an, hadith Rasulullah SAW dan syair Arab.

Ibn al-Atsir dikesan tidak membuat kritikan terhadap mana-mana maklumat yang diambil daripada Tarikh al-Tabari. Menurut beliau, ulasan dan kritikan tidak perlu ditambah berikutan keperibadian dan keilmuan al-Tabari yang tinggi serta dapat dilihat berdasarkan kitab-kitabnya yang mencakupi pelbagai bidang. Selain itu, metode pensejarahan alTabari, yaitu kronologi atau urutan peristiwa, turut menjadikan kitab Tarikh al-Tabari semakin unik dan dijadikan rujukan utama dalam al-Kamil fi al-Tarikh. Hal sedemikian menjelaskan lagi penghormatan Ibn al-Atsir terhadap al-Tabari dan kebergantungannya terhadap kitab Tarikh al-Tabari dapat dilihat pada metode penulisan dan isi kandungan sejarah al-Kamil fi al-Tarikh.

Karya Ibn Al-Atsir ini mempunyai signifikasi tersendiri, terutama dimulai dari juz 7 karena mencatat peristiwa-peristiwa yang dekat dengan masa hidup penulisnya. Kajian dari tahun $450 \mathrm{H}$. ini memaparkan benturan antara BaratKristen dengan Dunia Arab atau lebih dikenal dengan Perang Salib. Karya Ibn AlAtsir ini termasuk sumber primer mengenai Perang Salib Orientalis De Slane telah mempublikasikan karya Ibn Al-Atsir berikut terjemahannya dalam bahasa Prancis dalam kompilasi Sejarah Perang Salib

Hal menarik dari kitab ini ialah karena kitab ini sangat concern terhadap sejarah Dinasti Atabeg di Mosul, Irak hingga tahun 607 H/1211 M, ekspansi para penguasa Turki ke wilayah Aleppo dan Damaskus, dan perpecahan kerajaan mereka hingga hanya sebatas Mosul.

Sedangkan uraiannya mengenai pahlawan Muslim Shalahuddin terbilang aneh karena berisi sentimen pribadi terhadap Shalahuddin meskipun tetap mengakui kepahlawanannya. Ibn Al-Atsir melukiskan bahwa Shalahuddin adalah pahlawan yang memanfaatkan segenap kekuatan militernya untuk memenuhi ambisi keluarga dan membangun Dinasti Ayyubiyah. Oleh karena itu, ibnu alAtsir memberikan kritik yang sangat pedas terhadap Shalahuddin walaupun terkadang ia tidak dapat menggerakan penanya ketika melihat kesuksesan Shalahuddin. Dia menggambarkannya sebagai seorang pahlawan, akan tetapi pahlawan yang mencurahkan kekuatan politik dan taktik perangnya untuk dirinya sendiri dan keluarganya. Yang jelas penilaian ini dipengaruhi kedekatan Ibn AlAtsir dengan para penguasa Turki.

Ibn al-Atsir juga mencermati sejarah umat Islam di wilayah Timur dan Barat Islam pasca Shalahuddin, perpecahan mereka dan pengaruhnya saat menghadapi invasi pasukan Salib dan Tartar.

\section{Kelebihan al-Kâmil Ibn al-Atsir dari al-Târîkh al-Thabari}


Meskipun secara asal kitab Ibn al-Atsir ini bersandar kepada kitab Târîkh al-Rusul wa al-Mulûk karya Imam al-Thabari, bahkan sering disebut-sebut sebagai ringkasan darinya, dan Ibn al-Atsir pun sering menyebutnya dalam berbagai tempat, namun Ibn al-Atsir memiliki kelebihan dibandingkan dengan karya al-Thabari.

Pertama, Ibn al-Atsir menyebutkan peristiwa-peristiwa yang tidak disampaikan oleh Imam al-Thabari. Hal ini sangat wajar dikarenakan Ibn al-Atsir hidup sampai permulaan abad ke-7, sedangkan al-Thabari hidup sampai awal abad ke-4. Sehingga selain berhasil mengungkapkan peristiwa yang disebutkan alThabari, Ibn al-Atsir juga berhasil merekam peristiwa-peristiwa yang tidak dialami oleh al-Thabari.

Kedua, Ibn al-Atsir mengkritisi al-Thabari dikarenakan, meskipun alThabari menyebutkan secara kronologis beberapa ekspansi yang dilakukan ummat di belahan Timur dan Barat, namun al-Thabari tidak menyebutkan secara rinci mengenai teknis ekspansinya, terutama di daerah daerah terkenal seperti Ba'labak, Tripoli, Beirut, dan yang lainnya. Menurut Ibn al-Atsir, penyebutan teknis ekspansi ini sangat penting untuk menjadi pelajaran bagi ummat Islam dalam menjaga perbatasan kekuasaannya. Dalam bab ini, Ibn al-Atsir merujuk pada kitab Futûh al-Buldân karya al-Baladzuri.

Dan ketiga, Ibn al-Atsir menampung berita mengenai Islam di daerah Barat (maghrib) yang sangat rinci. Berita rinci ini tidak didapatkan dalam karya al-Thabari, bahkan dalam semua karya sejarah lainnya, baik yang klasik bahkan yang kontemporer. ${ }^{11}$

Selain ketiga poin di atas, secara keseluruhan Ibn al-Atsir memiliki kelebihan dalam meyakinkan apa yang dikutipnya, sekaligus mengkritik sumbersumber yang dia ambil darinya, dan perimbangannya terhadap sejarah berbagai kota yang ada di dunia Islam, dengan gaya perbandingannya yang memadai. Kelebihan lainya ialah gaya ungkapanya yang cemerlang, sederhana, dan hidup, yang memudahkan pembacanya untuk mengikuti dan mencermati tulisannya.

\section{Metodologi penulisan Ibn al-Atsir dalam Kitab al-Kâmil}

Ada beberapa pedekatan metodologis yang dilakukan Ibn al-Atsir dalam al-Kâmil, yaitu:

Pertama, Ibn al-Atsir menyebutkan sejarahnya berdasarkan urutan kronologis.

Kedua, beliau merangkum riwayat-riwayat yang menyebutkan beberapa kejadian yang sama, sehingga tidak membuat para pembacanya jenuh. Tahap ini bisa disebut tahap heuristik.

Dalam permulaan muqaddimah kitab tersebut Ibn al-Atsir berkata:

${ }^{11}$ Ibn al-Atsir, al-Kâmil fí al-Târîkh, h. J. 


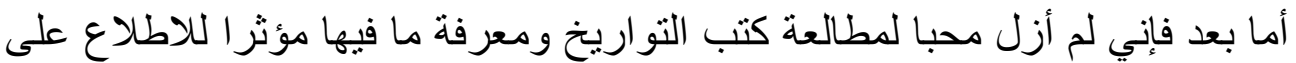

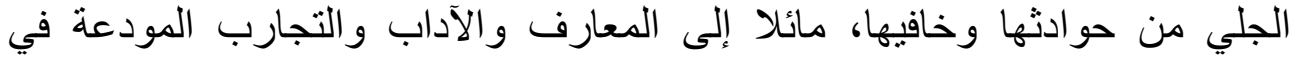

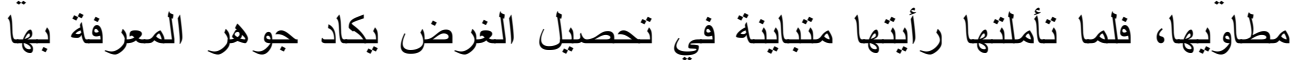

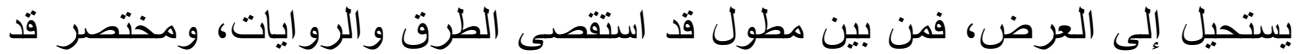

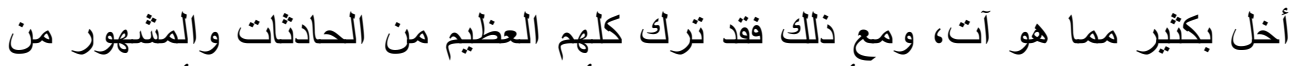

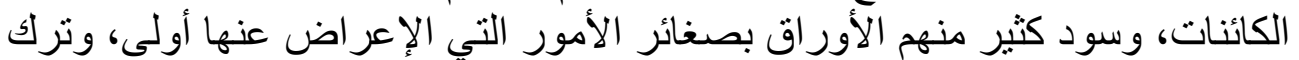

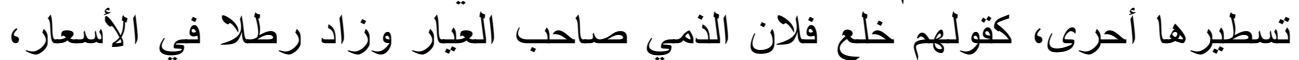

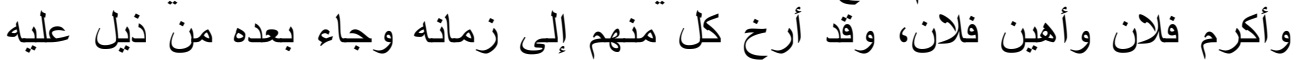

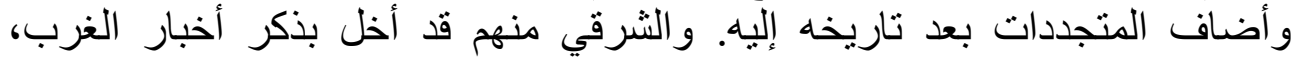

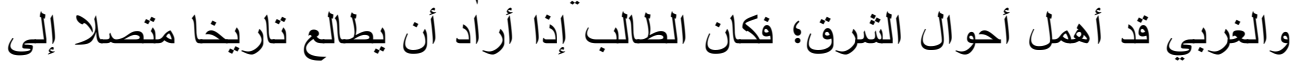

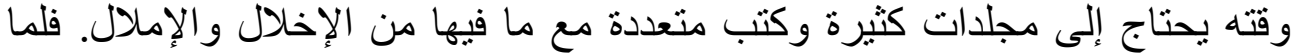

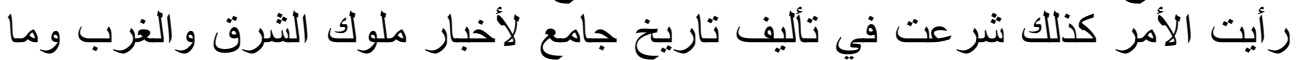

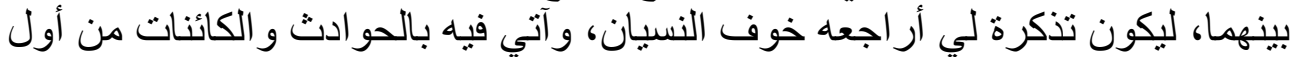

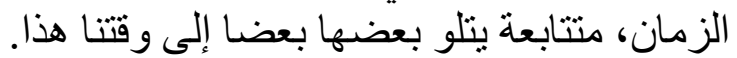

“Amma ba'd. Aku sangat senang menelaah kitab-kitab sejarah ketika aku mengamatinya, aku melihat bahwa setiap kitab memiliki tujuan berbeda. Tujuan yang berbeda ada orang yang sengaja memperpendek riwayat yang seharusnya ditulis dalam lembaran yang panjang. Sebaliknya ada pula orang yang ingin memanjangkan cerita untuk urusan yang sangat kecil. Orangorang timur tidak suka membuat sejarah orang Barat, sedangkan orangorang Barat mengabaikan suasana yang sedang terjadi di Timur. Oleh sebab itu, jika ada pelajar yang hendak mengkaji sejarah secara kronologis dan terus bersambung, dia mesti mengkajinya dalam waktu yang lama, untuk menelaah berjilid-jilid kitab, padahal hal seperti ini sangat membosankan. Ketika saya melihat suasana seperti ini, saya mulai mencoba menulis sejarah secara menyeluruh, dengan mengulas peristiwa dari awal secara berurutan hingga zaman kita sekarang ini."

Ketiga, Ibn al-Atsir hanya mengutip riwayat-riwayat yang telah teruji kebenarannya. Langkah ini merupakan hal yang tidak sulit bagi orang sekelas Ibn al-Atsir yang terkenal keahliannya dalam ilmu hadits. Tahap ini bisa disebut sebagai tahap kritik. Tahap dimana seorang sejarawan harus memilah data mana yang layak untuk diangkat menjadi sebuah fakta.

Keempat, setelah berhasil menghimpun riwayat-riwayat yang sudah teruji, maka Ibn al-Atsir menyusunnya dalam sebuah tema dengan urutan yang bersesuaian dan berkesinambungan. Tahap ini disebut sebagai tahap interpretasi. Ibn al-Atsir menyatakan:

$$
\begin{aligned}
& \text { فجمعت أنا الحادثة في موضع و احد وذكرت كل شيء منها في أي شهر أو سنة كانت }
\end{aligned}
$$

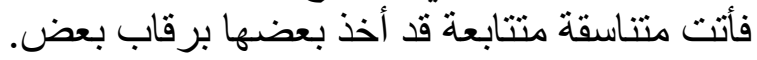

Maka aku mengumpulkan riwayat-riwayat (yang sudah teruji) tersebut dalam sebuah rangkaian yang teratur berdasar bulan atau tahunnya. Dan aku 
menglasnya menjadi rangkaian peristiwa kronologis yang teratur dan berkesinambungan. ${ }^{12}$

Kelima, Ibn al-Atsir menguji peristiwa sejarah dengan pendekatan ilmuilmu bantu yang bersesuaian dengan pembahasannya. ${ }^{13}$

Keenam, Ibn al-Atsir menilai sebuah sejarah dengan pendekatan kontinuitas. Bahkan Ibn al-Atsir berhasil mengungkap sebuah peristiwa berdasarkan aspek-aspek yang mengitarinya, mulai dari aspek sosiologis, antropologis, dan kejadian kronologis sebelumnya. ${ }^{14}$

\section{Sistematika Penulisan Kitab al-Kâmil fi al-Târîkh}

Kitab yang pertama kali dicetak di Leiden kemudian di Mesir ini merupakan kitab sejarah yang berbicara mulai dari awal penciptaan sampai tshun $628 \mathrm{H}$.

Pada jilid pertama Ibn al-Atsir membuka kitabnya dengan muqaddimah yang mencakup penjelasan tentang manfaat mempelajari ilmu sejarah serta metodologi penulisannya. Kemudian Ibn al-Atsir mulai pembahasan awal penciptaan, kisah para nabi sampai naiknya Isa ibn Maryam dengan diselingi kisah para raja Romawi. Pembahasan jilid pertama ini sampai dengan pembahasan masa menjelang diutusnya Nabi Saw sampai tahun ke-11 hijrah. Jilid kedua dimulai dengan pembahasan sakit dan wafatnya Nabi Saw dan berakhir sampai tahun 65 H. Pada jilid ketiga pembahasan sampai tahun 168 H. Jilid keempat sampai akhir kekhalifahan al-Muqtadir pada tahun $295 \mathrm{H}$. Jilid kelima sampai tahun $412 \mathrm{H}$. Jilid keenam sampai tahun $527 \mathrm{H}$. Dan jilid ketujuh sampai tahun $628 \mathrm{H}$. Jilid ketujuh ini merupakan jilid yang paling penting karena ditulis berdasarkan persaksian matanya sendiri. Dan pada jilid ketujuh ini juga Ibn alAtsir mengalami penyimpangan dalam menuliskan kisah Shalahuddin al-Ayubi.

\section{Perbandingan Pemaparan al-Thabari dan Ibn al-Atsir mengenai Tanah Fadak}

Untuk membutikan kepeloporan Ibn al-Atsir dalam Ilmu Sejarah, penulis akan mencoba memaparkan keterangan al-Thabari mengenai Tanah Fadak dan akan disusul oleh keterangan dari Ibn al-Atsir sebagai bahan perbandingan. Maka dengan cara seperti itu akan terlihat jelas sejauh mana keunggulan Ibn al-Atsir, baik dari segi informasi maupun analisisnya dibandingkan karya al-Thabari.

\section{Pemaparan Ibn Jarir al-Thabari}

Dalam memaparkan kasus Fadak ini, al-Thabari menampilkan beberapa jalur riwayat. Dimana satu riwayat dengan yang lainnya saling memberikan

\footnotetext{
${ }^{12}$ Ibn al-Atsir, al-Kâmil fì al-Târîkh h. 7.

${ }^{13}$ Ibn al-Atsir, al-Kâmil fí al-Târîkh, h. S.

${ }^{14}$ Ibn al-Atsir, al-Kâmil fí al-Târîkh, h. S.
} 
informasi tambahan. Menurut riwayat yang ditampilkan oleh al-Thabari, ketika Rasulullah Saw selesai menaklukan Khaibar, dan kabar tersebut sampai kepada penduduk Fadak, Allah memasukkan rasa gentar ke dalam perasaan mereka. Maka mereka mengutus seorang delegasi untuk mengajak berdamai kepada Rasulullah dengan jaminan penyerahan setengah tanah Fadak. Setelah Rasulullah kembali ke Madinah, Rasulullah menerima tawaran dari penduduk Fadak tersebut. Maka dengan begitu tanah Fadak adalah khusus milik Rasulullah karena ditaklukan tanpa usaha apapun. ${ }^{15}$

Kemudian al-Thabari menyusul penjelasan tersebut dengan riwayat lain dari Abdullah ibn Abu Bakar, bahwa Rasulullah mengutus Abdullah ibn Rawahah kepada penduduk Khaibar sebagai penengah antara mereka dengan kaum muslimin. Namun mereka malah mengatakan bahwa kaum muslimin telah memulai permusuhan dengan mereka.

Setelah Abdullah ibn Rawahah terbunuh pada perang Mu'tah, maka posisi penengah dengan Khaibar digantikan oleh Jabbar ibn Shakhr ibn Khansa' dari Bani Salimah. Perjanjian antara penduduk Khaibar dan kaum muslimin berjalan secara baik sampai orang Khaibar melanggar perjaniannya dengan membunuh Abdullah ibn Sahl dari Bani Haritsah. Maka Rasulullah mengusir mereka semuanya. ${ }^{16}$

Al-Thabari juga mengutip riwayat dari Ibn Syihab yang menyebutkan bahwa Rasulullah saw. menaklukan Khaibar dengan pengepungan. Khaibar adalah tanah $f a$ ' $i$ (harta rampasan yang didapat tanpa peperangan) yang diberikan oleh Allah kepada Rasulullah. Maka ketika Rasulullah memasuki Khaibar, para penduduk Khaibar lari meninggalkan tanah mereka. Maka Rasulullah memanggil mereka untuk memberikan penawaran. Rasulullah menawarkan kepada mereka supaya mereka tetap tinggal di Khaibar untuk menggarap tanah-tanah yang terdapat di dalamnya. Adapun hasilnya maka akan dibagi untuk mereka dan untuk kaum muslimin. Akhirnya merekapun menerima tawaran tersebut. Maka Rasulullah mengangkat Abdullah ibn Rawahah sebagai pengawas tanah Khaibar. Abdullah membagikan hasil tanah Khaibar dengan mereka dan merekapun mengakui keadilan Abdullah. ${ }^{17}$

Setelah Rasulullah Saw wafat, Abu Bakar meneruskan kebijakannya ini selama masa pemerintahannya. Begitu juga dengan Umar ibn Khaththab di awalawal pemerintahannya. Namun ketika sampai kepada Umar mengenai pesan dari

${ }^{15}$ Al-Thabari, Târîkh al-Rusul wa al-Muluk, cet, ke-2, (Beirut: Dar al-Turats, 1387 H), juz 3, hal. 19.

${ }^{16}$ Al-Hamadzani, Takmilat Târîkh al-Thabarî, (Beirut: Maktabah Katolikiyyah, 1958), h. 76.

${ }^{17}$ Al-Hamadzani, Takmilat Târîkh al-Thabarî, h. 76. 
Rasulullah menjelang wafat bahwa tidak boleh ada dua agama di Jazirah Arab, maka Umar mengutus seseorang untuk menyampaikan pesan tersebut kepada penduduk Khaibar. Umar menyuruh siapa saja di antara penduduk Khaibar yang memiliki perjanjian dengan Rasulullah supaya menghadap langsung kepada Umar untuk dilunasi. Namun Umar menyuruh kepada siapapun dari penduduk Khaibar yang tidak memiliki perjanjian apapun dengan Rasulullah supaya bersiap-siap untuk meninggalkan tanah Khaibar. Akhirnya Umar pun benar-benar mengusir mereka dari tanah Khaibar. ${ }^{18}$

Al-Thabari menutup penjelasannya dengan beberapa kejadian yang terjadi pada tahun tersebut dengan mengutip penjelasan dari al-Waqidi. Menurut alWaqidi pada tahun ini Rasulullah Saw menyerahkan Zainab binti Rasulullah kepada Abu al-'Ash ibn Rabi' dan hal itu terjadi pada bulan Muharram. Pada tahun yang sama Hathib ibn Abi Balta'ah, yang diutus oleh Rasulullah menghadap Muaqauqis (penguasa Mesir), kembali ke Madinah dengan membawa Mariyah al-Qibthiyyah dan sudarinya yang bernama Sirin sebagai hadiah dari Muaqauqis. Maka Rasulullah mengirimkan Sirin kepada Hasan ibn Tsabit. Pada tahun ini juga Rasulullah mengutus Umar ibn Khaththab bersama 30 pasukan ke daerah Hawazin. Pada tahun ini juga, tepatnya pada bulan Sya'ban, Abu Bakar diutus untuk melakukan ekspedisi ke Najd. ${ }^{19}$

\section{Pemaparan Ibn al-Atsir}

Ibn al-Atsir mengutip beberapa riwayat dari al-Thabari tanpa berpanjang lebar dengan beberapa riwayatnya. Ibn al-Atsir terkesan meringkas semua penjelasan al-Thabari dengan beberapa tambahan keterangannya dalam satu penjelasan. Menurut Ibn al-Atsir, ketika Rasulullah saw. pergi meninggalkan Khaibar, Rasulullah mengutus Mahishah ibn Mas'ud kepada penduduk Fadak untuk mengajak mereka masuk Islam. Pemimpin mereka pada waktu itu adalah Yusya' ibn Nun al-Yahudi. Mereka mengajukan penawaran membayar jizyah dengan menyerahkan setengah dari tanah mereka. Dan Rasulullahpun menerima penawaran mereka. Setengah dari tanah Fadak tersebut adalah murni milik Rasulullah saw karena tanah tersebut diserahkan tanpa adanya kontak fisik sedikitpun. Hasil dari penggarapan tanah tersebut diberikan kepada Ibn Sabil. Penduduk Fadak tetap menempati tanah mereka sampai dengan kekhilafahan Umar ibn al-Khaththab. Umar mengintruksikan supaya mengusir seluruh Yahudi dari tanah Hijaz. Umar mengutus Abu al-Haitsam ibn al-Tihan, Sahl ibn Abu Hatsmah, dan Zaid ibn Tsabit upaya membayar harga setengah tanah mereka dan mengusir mereka ke Syam. ${ }^{20}$

\footnotetext{
${ }^{18}$ Al-Thabari, Târîkh al-Rusul wa al-Muluk, cet, ke-2, juz 3, h. 21.

${ }^{19}$ Al-Thabari, Târîkh al-Rusul wa al-Muluk, cet, ke-2,juz. 3, h. 22.

${ }^{20}$ Ibn al-Atsir, al-Kâmil fì al-Târîkh, juz. 2, h. 102.
} 
Ibn al-Atsir tidak hanya terpaku pada penjelasan yang diutarakan alThabari secara kronologis. Ibn al-Atsir mencoba menjelaskan alur cerita secara lebih utuh dengan menambah keterangan yang terjadi setelah masa kenabian. Ibn al-Atsir menambahkan keterangan dengan menyatakan bahwa ketika masa pemerintahan Mu'awiyyah, Marwan ibn. al-Hakam mengambil alih tanah Fadak tersebut dan menghibahkannya kepada kedua anaknya yang bernama Abdul Malik dan Abdul Aziz. Kemudian tanah tersebut jatuh ke tangan Umar ibn Abdul Aziz. Ketika Sulaiman ibn Abdul Malik menduduki tahta kekhalifahan, maka dia menyerahkan jatah tanah Fadaknya kepada Umar ibn Abdul Aziz. Maka ketika Umar ibn Abdul Aziz diangkat menjadi khalifah, maka Umar ibn Abdul Aziz berkhutbah di hadapan rakyatnya dan memberitahukan kepada mereka semua mengenai urusan tanah Fadak. Umar mengumumkan bahwa tanah fadak akan difungsikan kembali sebagaimana pada masa Rasulullah, Abu Bakar, Umar, Utsman, dan Ali. Maka Umar menyerahkan pengurusan tanah Fadak tersebut kepada anak-anak Fathimah binti Rasulullah. Namun pada tahun 210 H, alMa'mun mengambil kembali tanah fadak tersebut dari mereka. ${ }^{21}$

Peristiwa Khaibar Rasulullah saw. menyerahkan Zainab binti Rasulullah kepada Abu al-'Ash ibn Rabi', dan hal itu terjadi pada bulan Muharram. Pada tahun yang sama Hathib ibn Abi Balta'ah, yang diutus oleh Rasulullah menghadap Muaqauqis (penguasa Mesir), kembali ke Madinah dengan membawa Mariyah al-Qibthiyyah dan sudarinya yang bernama Sirin sebagai hadiah dari Muaqauqis. Maka Rasulullah mengirimkan Sirin kepada Hasan ibn Tsabit. Pada tahun ini juga Rasulullah mengutus Umar ibn Khaththab bersama 30 pasukan ke daerah Hawazin. Dan pada tahun ini juga, tepatnya pada bulan Sya'ban, Abu Bakar diutus untuk melakukan ekspedisi ke Najd. ${ }^{22}$

Menurut Ibn al-Atsir, pada tahun tersebut terjadi ekspedisi yang dipimpin oleh Ghalib ibn Abdullah al-Laitsi ke daerah Bani Murrah. Maka di tengah perjalanan mereka berhasil salah satu mata-mata mereka yang bernama Mirdas ibn Nuhaik. Kemudian ketika dia hendak dibunuh dia mengucapkan kalimat syahadat. Namun Usamah ibn Zaid dan salah seorang dari Anshar tetap membunuhnya. Maka ketika kabar tersebut sampai kepada Rasulullah Saw, Rasulullah menegur perbuatan mereka. ${ }^{23}$

Pada tahun tersebut juga terjadi ekspedisi yang dipimpin oleh Basyir ibn Sa'd ke daerah Yaman dan daerah selatan pada bulan Syawal. Penyebab dari kejadian ini adalah dikarenakan seorang penunjuk jalan ketika Rasulullah menuju Khaibar, yang bernama Husail ibn Nuwairah al-Asyja'i menghadap kepada Nabi

\footnotetext{
${ }^{21}$ Ibn al-Atsir, al-Kâmil fí al-Târîkh, juz. 2, h. 103.

${ }^{22}$ Ibn al-Atsir, al-Kâmil fí al-Târîkh, juz. 2, h. 103

${ }^{23}$ Ibn al-Atsir, al-Kâmil fì al-Târîkh, juz. 2, h. 104.
} 
Saw, dan memberitahukan bahwa sekelompok dari Bani Gathafan di daerah selatan dihasut oleh Uyainah untuk menyerang Madinah. Maka Rasulullah mengutus Basyir untuk mengintai mereka. Maka mereka bertemu dengan pasukan Uyainah dan berhasil menumpas pergerakan mereka setelah sebelumnya berhasil membunuh mata-mata mereka. ${ }^{24}$

\section{Perbandingan Pemaparan antara al-Thabari dan Ibn al-Atsir}

Dalam memaparkan kisah Tanah Fadak, al-Thabari memasukkannya dalam pembahasan pembagian ghanimah Khaibar secara umum. Sedangkan Ibn al-Atsir membuat bab khusus mengenai hal ini. Meskipun dari segi informasi dan kronologis peristiwa sejarahnya bisa dikatakan mirip, untuk tidak mengatakan sama.

Dalam mengurai peristiwa ini, al-Thabari sangat kental dengan ilmu haditsnya. Al-Thabari menyebutkan persitiwa yang sama dengan beberapa sanad yang berbeda. Hal ini mengingatkan penulis kepada metode Imam Muslim dalam menyusun kitab shahih-nya. Dengan pemparan berbagai sanad tersebut, seorang pembaca yang tidak biasa dengan ilmu hadits akan merasa jenuh dan pembahasan kesejarahannya akan terasa kering. Namun bagi pembaca yang terbiasa dengan karya al-Thabari ini, pasti akan memahami bahwa apa yang diulang-ulang oleh alThabari, selain sebagai data penguat, adalah untuk memberikan tambahan signifikansi dan informasi. Terkadang dalam satu jalur periwayatan tercantum informasi yang tidak terdapat dalam riwayat yang lainnya.

Adapun Ibn al-Astir, beliau tidak lagi menggunakan metode seperti alThabari. Meskipun memiliki background keilmuan yang sama dengan al-Thabari sebagai ahli hadits, namun Ibn al-Atsir tidak terlalu terbebani dengan masalah periwayatan. Oleh karena itu, pembaca akan merasa lebih merasakan citarasa kesejarahannya. Meskipun harus diakui, bahwa informasi yang dituangkan oleh Ibn al-Astir adalah berasal dari al-Thabari.

Namun ada hal baru yang diketengahkan oleh Ibn al-Atsir. Ibn al-Atsir memperlihatkan alur kesejarahan secara lebih utuh, meskipun beliau harus menerangkannya sampai keluar dari masa yang sedang dia bahas. Sehingga pembaca mendapatkan informasi lebih utuh. Jadi bisa dikatakan bahwa Ibn alAtsir menggabungkan keterangan kronologis dan tematis. Metode ini tidak ada pada tulisan al-Thabari.

Kelebihan lain yang ditampilkan oleh Ibn al-Atsir adalah ketika beliau menjelaskan kronologis kejadian perang yang lebih detail. Bahkan Ibn al-Atsir menjelaskan langkah-langkah ekspedisi yang dilakukan oleh para sahabat Rasulullah, seperti membunuh mata-mata musuh sebagai langkah awal dari

${ }^{24}$ Ibn al-Atsir, al-Kâmil fî al-Târîkh, juz. 2, h. 105. 
penyerangan dan yang lainnya. Sehingga informasi yang disampaikan bukan hanya informasi kesejarahan, tapi juga ilmu kemiliteran.

\section{E. Kesimpulan}

kitab Ibn al-Atsir ini memiliki beberapa kelebihan yang bisa dirangkum dalam dua aspek; Pertama, dari segi objek materialnya, kitab ini lebih informatif dan juga lebih teruji kebenarannya dari pada kitab-kitab sebelumnya. Bahkan dari kitab kontemporer sekalipun.

Kedua, dari segi objek formalnya, kitab ini berhasil mengungkap sebuah kejadian dengan pisau analisis yang sangat baik. Metode penelitiannya bisa dikatakan mendahului sejarawan Barat secara khususnya, dan seluruh sejarawan pada umumnya.

Ketiga, karya Ibn al-Atsir ini merupakan karya penyempurna bagi karya al-Thabari. Posisinya sebagai penyempurna menyebabkan Ibn al-Atsir tidak bisa keluar dari urutan kronologis yang dibuat oleh al-Thabari. Bahkan kalaupun Ibn al-Atsir melakukan lompatan yang lebih tinggi dari al-Thabari, itu dikarenakan Ibn al-Atsir melompat dari ketinggian al-Thabari.

\section{DAFTAR PUSTKA}

Al-Hamadzani, Takmilat Târîkh al-Thabarî, Beirut: Maktabah Katolikiyyah, 1958.

Ajid Thahir, Sirah Nabawiyyah, Bandung: Marja, 2014.

Al-Shafadi, al-Wâfî wa al-Wâfiyât, KSA: Dar al-Salam, 1999.

Al-Thabari, Târîkh al-Rusul wa al-Muluk, cet, ke-2, Beirut: Dar al-Turats, 1387

$\mathrm{H}$.

Ibn Khalikan, Wafayât al-A'yân, Beirut: Dar al-Fikr, 2000.

Ibn al-Atsir, al-Kâmil fî al-Târîkh Beirut: Dar al-Kutub al-'Arabi, 1997.

Usud al-Ghâbah fî Tamyîz al-Shahâbah, Mesir: Dar al-Kutub al'Ilmiyyah, 1994, dicetak dalam 8 jilid.

Koes Adiwijajanto, Historicum Camalitatum Dunia Islam dalam Historiografi Ibn al-Atsir, Jurnal Cordoba, Vol. 1, no.1, 2017.

Muhammad Zolfazdli, dkk., Pembahasan Sejarah di India dalam al-Kâmil fî alTârikh, Jurnal Islamiyyat, no.2, 2013.

Syamsuddin al-Dzahabi, Târîkh al-Islâm, Damaskus: Dar al-Fikr, 2002.

Tajuddin Al-Subki, Thabaqât al-Syâfi'iyyah al-Kubrâ, Mesir: Maktabah alTijariyah, 1994. 